\title{
One-Time Pruning of Pecan Trees Induced Limited and Short-Term Benefits in Canopy Light Penetration, Yield, and Nut Quality
}

\author{
Leonardo Lombardini ${ }^{1}$ \\ Texas A\&M University, Department of Horticultural Sciences, TAMU 2133, \\ College Station, TX 77843-2133
}

Additional index words. Carya illinoinensis, light interception, leaf area index, selective pruning, hedging

\begin{abstract}
Twenty-five-year-old 'Cape Fear', 'Desirable', and 'Kiowa' pecan [Carya illinoinensis (Wangenh.) C. Koch] trees were either not pruned, or subjected to single selective or mechanical pruning using a mechanical hedger [or hedge pruning (HP)] in the dormant season 2003. Canopy light interception, yield, and nut quality were monitored during a period of three years. Leaf area index and light interception were significantly affected during the first growing season after treatment application, but after three years canopies grew back to control levels. In general, there were small positive effects observed on yield and nut quality after pruning. Minor improvements were recorded for 'Desirable', in which yield was affected positively by both pruning strategies in 2004. However, most effects disappeared by the third year. 'Desirable' responded better than 'Cape Fear', whereas no beneficial effects were recorded on 'Kiowa'. In 2005, yield was significantly reduced in HP trees of 'Cape Fear' and 'Kiowa'. Alternate bearing index was unaffected by pruning treatment or cultivar. Kernel percentage increased only in HP 'Desirable' trees in 2003 and 2004. Kernel quality was improved in HP 'Cape Fear' and 'Desirable' in the first growing season after treatment application, but not in 2004. In 2005, quality was again improved in HP 'Desirable'. The results of the current study indicate that one-time pruning of pecan trees induce positive short-term effect on light, but not necessarily an increase in productivity and nut quality.
\end{abstract}

Tree crowding is a phenomenon that pecan growers have to face during their production cycle. The onset of tree crowding depends mainly on tree spacing, but soil depth, growth rate, and tree architecture play a role as well. In a commercial orchard with trees planted at the common spacing of $10.7 \times$ $10.7 \mathrm{~m}$, growers should start canopy management practices when trees are in their 12th to 15 th leaf season.

A decline in tree productivity and health associated with crowding should not be attributed to natural tree senescence, because there is no known upper age limit for pecan production (Worley, 1990). Pecan trees begin to bear fruits within six to 10 years from planting and continue to produce for decades. Records indicate that native trees more than 150 years old can produce an average annual crop of over $200 \mathrm{~kg} /$ tree (Brison, 1974).

\footnotetext{
Received for publication 31 Mar. 2006. Accepted for publication 12 June 2006. This project was funded in part by the Texas Agricultural Experiment Station. Mention of a trademark, proprietary product, or vendor does not constitute a guarantee or warranty of the product by the authors, the Texas A\&M Univ., the Texas Agricultural Expt. Sta., or sponsors of the research and does not imply its approval to the exclusion of other products or vendors that also may be suitable.

${ }^{1}$ To whom reprint requests should be addressed; e-mail 1-lombardini@tamu.edu.
}

Competition for nutrients, water, and light are likely the prevalent cause of the progressive weakening of crowded cultivated trees. Woodroof and Woodroof (1934) reported that in a 10 -year-old pecan tree, the spread of the root system is about double the diameter of the canopy, thus explaining why, in orchard plantings, competition can become particularly severe when tree canopies of neighboring trees start touching.

Crowding induces reduction in number of flowers, productivity, and percent kernel, and it has been indicated as one of the possible causes for increase in alternate bearing (McEachern and Stein, 2003; Wood, 1990). Moreover, when trees are crowded, lower limbs begin to die, the bearing surface is reduced in volume, and the fruit is born higher in the canopy and becomes more difficult to manage. Crowding reduces the amount of light intercepted per unit of leaf area, thus decreasing the efficiency of carbon assimilation, and decreases air movement while increasing drying time after rain or dew events, which may result in a greater probability of diseases, such as pecan scab [Cladosporium caryigenum (Ell. et Lang.) Gottwald] (Brison, 1974; Latham and Goff, 1990).

The beneficial effects of pruning pecan trees have been proved by several studies. When the height of 'Stuart' trees was gradually reduced by removing one to three limbs per year, tree vigor, terminal shoot growth, and nut size were improved, although the yield was reduced (Worley and Mullinix, 1997). Results from a 20 -year hedging program conducted in Australia on 'Western' and 'Wichita' trees indicated that mechanized hedge pruning and topping returned better nut yield than treatments that reduced crowding by removing selected trees (Wood and Stahmann, 2004). Despite the known benefits and the several approaches from which to choose, pruning as a cultural practice has not yet been widely adopted in pecan orchards. The tendency has been to allow trees to grow until canopies begin to touch and then remove trees. However, removal of mature, bearing, healthy trees at the peak of their productivity is a difficult option for pecan producers, who have invested years of resources to culture the trees. The tendency to delay tree thinning has also resulted in many orchards with trees that exceed $20 \mathrm{~m}$ in height and show typical symptoms of tree crowding.

Mechanical hedging is a common practice to prevent orchard crowding in the areas characterized by dry environments, such as New Mexico and western Texas, where trees are planted closer than in other production areas. When trees crowd, hedge pruning can be a useful management tool to improve light penetration into and interception by pecan orchards. Malstrom and colleagues (1982) tested mechanical hedge pruning on mature 'Western' pecan trees in the lower El Paso valley in Texas, and found that pruning increased the amount of light penetration into the orchard. The study reported that the fraction of total solar radiation measured under pruned and unpruned trees was $35 \%$ and $16 \%$ respectively. Mechanical hedging caused increase light penetration between trees but not within individual tree canopies, which may explain why production and nut quality were unaffected (Malstrom et al., 1982).

As a result of the high costs associated with hedging, selective pruning is an option that some growers choose to open up crowded orchards. Such an approach is typically less expensive than mechanical canopy hedging, especially in those regions where hedging equipment is less readily available, but it is not as effective in removing tree canopy and can be also very labor intensive and dangerous for the operators.

The objective of this study was to compare light interception and productivity of unpruned mature pecan trees with those of one-time mechanically hedged and selectively pruned trees in crowded pecan orchards. The hypothesis was that the two methods would be equally effective in removing a portion of the tree canopies, increasing the amount of solar radiation intercepted by the trees, and improving yield and nut quality.

\section{Materials and Methods}

Site

The experiment was conducted in a in a commercial, nonirrigated 25 -year-old pecan orchard located in the Brazos River 
bottom near Caldwell, Tex. (lat. $30^{\circ} 36^{\prime} \mathrm{N}$, long. $\left.96^{\circ} 30^{\prime} \mathrm{W}\right)$. The size of the orchard was about 180 ha, and the soil type was a silt loam, $0 \%$ to $1 \%$ slope, belonging to the Coarsewood series, which is defined as very deep, well-drained, moderately rapidly permeable soils that formed in calcareous, loamy alluvium (Soil Survey Staff, 2004). The orchard area chosen for the study was selected based on uniformity of tree size and vigor. All trees were spaced at $11.6 \times 11.6 \mathrm{~m}$ and had $45 \pm 8$-cm-diameter trunks measured at breast height $(\mathrm{DBH}=1.3 \mathrm{~m})$ at the beginning of the study. The selected trees and the guard trees occupied an area of about 3.6 ha. Before treatment establishment, trees had never received any type of pruning, and canopies touched in row middles.

Pests were controlled following the recommendations of the Texas Agricultural Extension Service for commercial pecan management. To control pecan scab, three, five, and three fungicide applications were done in the 2003, 2004, and 2005 growing seasons respectively. Visual observations of scab infestations were done each growing season, and only minor infestations were detected on leaves toward the end of each summer. More pesticide applications were done in summer 2004 because of elevated precipitation that year. Rainfall precipitation between 1 Apr. and 31 Oct. was 529 mm, 746 $\mathrm{mm}$, and $301 \mathrm{~mm}$ in 2003, 2004, and 2005 respectively.

\section{Treatment application}

Three blocks, each containing $90(9 \times 10)$ trees, were established in January 2003. Each block spanned across 10 north-south-oriented rows, four of which were planted with 'Cape Fear', two with 'Kiowa', and four with 'Desirable'. Between February and March 2003, each cultivar within each block received three pruning treatments, no pruning (NP), selective pruning (SP), and hedge pruning (HP). For SP, the limbs that extended over neighboring trees and those that clearly competed for light with adjacent limbs were pruned by an operator using a hydraulic tower and a chain saw. For HP, the east and west sides of each tree were pruned using a hedging machine with eight circle saws $90 \mathrm{~cm}$ in diameter that made two side cuts in the east-west direction of the canopies. Cuts were made at $4 \mathrm{~m}$ from either side of the trunk, so that an opening of about $3.6 \mathrm{~m}$ was left between the canopies of adjacent rows. The total above-ground dormant biomass removed from trees was visually estimated at $5 \%$ to $10 \%$ for the SP and $15 \%$ to $20 \%$ for HP. No pruning was done to NP trees.

Data were collected from two adjacent sample trees per cultivar treatment per block. Each sample tree was surrounded by the adjacent sample tree and seven guard trees, either within the same row or from the adjacent rows. In 'Cape Fear' and 'Desirable', all guard trees were of the same cultivar as the sample trees. In 'Kiowa', the eight guard trees were five 'Kiowa' trees and either three 'Cape Fear' or three 'Desirable'.
Trunk DBH was measured after each growing season for the duration of the study (2003-2005).

\section{Light interception}

Leaf area index (LAI), corresponding to the total one-sided leaf area per unit of ground surface area (Watson, 1947), and canopy light interception were measured on 'Kiowa' trees on 21 June 2003, 5 Aug. 2003, 2 July 2004, 17 Sept. 2004, 7 July 2005, and 11 Sept. 2005 using a ceptometer (AccuPAR; Decagon Scientific, Pullman, Wash.). Data were always collected on days characterized by sunny conditions. Before collecting the data from each tree, the "above canopy" photosynthetic photon flux density (PPFD) was recorded in an open field adjacent to the orchard, far enough to minimize any possible interference incited by the pecan tree canopies. For LAI determination, 16 readings per tree were taken near solar noon while moving along two concentric circles with a radius of $2.9 \mathrm{~m}$ and $5.8 \mathrm{~m}$ (i.e., one-fourth and one-half the orchard planting distance respectively; Fig. 1A). For canopy interception, a $11.6 \times$ $11.6-\mathrm{m}$ square was marked around each 'Kiowa' study tree and divided into a $6 \times 6$ square grid (Fig. 1B). Stakes were inserted in the soil at all 36 intersection corners of the grid to mark the site used to measure belowcanopy $P P F D$. Canopy light interception was expressed as a percentage of the daily incoming above-canopy PPFD and was plotted as contour plots using a graphing software package (Origin v. 7.5; OriginLab Corp., Northampton, Mass.)

\section{Yield and nut quality characteristics}

Fruits from each tree were harvested in early Nov. of each year using a hydraulic trunk shaker and a mechanical harvester. After crop weight per tree was determined, $\mathrm{a} \approx 400$-g sample of nuts per tree was collected for in-shell and kernel quality characteristics (Lombardini et al., 2005). Alternate bearing index $(I)$ was calculated using the formula indicated by Pearce and DoberšekUrbanc (1967) and used to express the fluctuation in yield during the time span of the experiment.

\section{Experimental design and statistical analysis}

The experimental design was a randomized complete block design nested within cultivar with three treatments per cultivar. Data were subjected to analysis of variance and, when applicable, means were separated using Fisher's LSD at $P \leq 0.05$ using SAS software (SAS Institute, Cary, N.C.).

\section{Results and Discussion}

After 3 years, there were no differences in trunk diameter across treatments (data not reported) and average diameter was $47.9 \pm$ $3.2 \mathrm{~cm}$.

Leaf area index is an important biological parameter because it defines the area that interacts with solar radiation and, consequently, the surface that is responsible for carbon absorption and exchange with the atmosphere (Breda, 2003). In SP, the portion of removed canopy was very localized (Fig. 2 ) and concentrated in those areas where big branches were removed. In HP, light transmission through the canopies increased mainly on the east and west sides - in other words, the hedged parts of the canopy (Fig 2). Leaf area index of 'Kiowa' trees was significantly affected by pruning during the first growing season after treatment application (Fig. 3). In 2003, LAI averaged 4.7, 3.2, and 2.0 in NP, SP, and HP respectively. These results indicate that about $32 \%$ and $57 \%$ of the leaf area was removed from SP and HP trees respectively. The modifications to the canopy density induced a proportiona increase in the fraction of total solar radiation intercepted by the tree canopies (Fig. 3). In 2003 , the fraction of solar radiation that reached the orchard floor in HP was about $43 \%$ of total solar radiation, which is close to the recommended value of $50 \%$ for optimal production (McEachern and Stein, 2003) and similar to the level obtained in a hedging experiment conducted in "Western" pecans

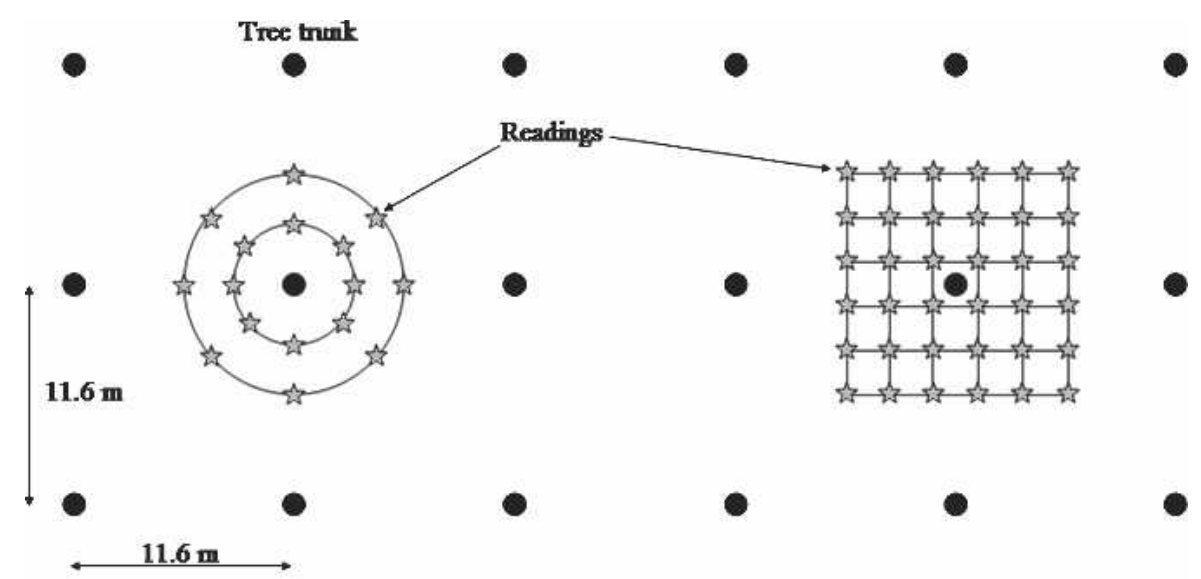

A

B

Fig. 1. (A, B) Guides followed to collect ceptometer readings to measure leaf area index (A) and solar radiation interception (B) in a mature pecan orchard subjected to three canopy pruning techniques. 


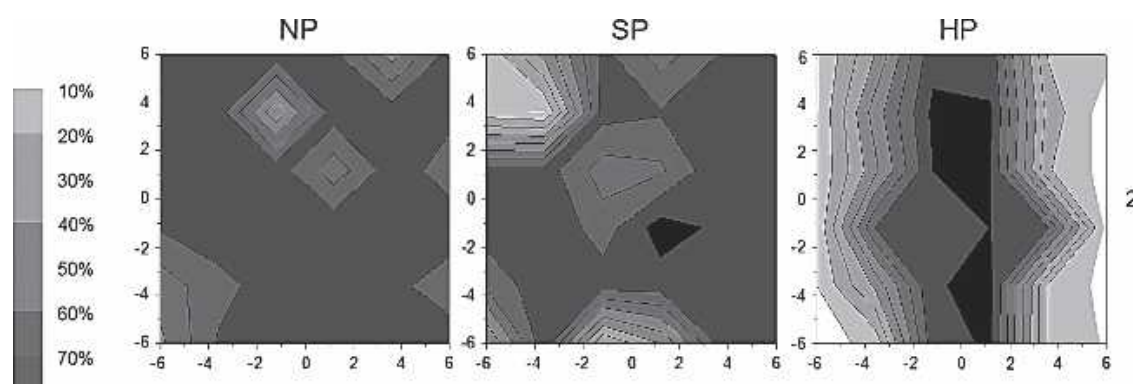

2003
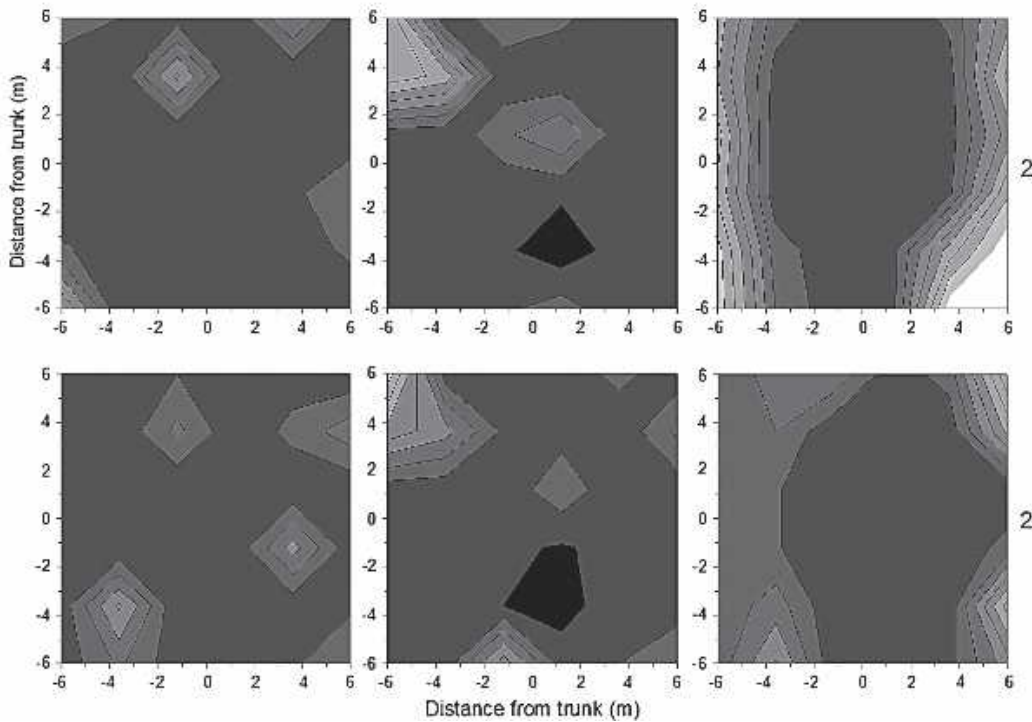

2005

Fig. 2. Patterns of light interception of canopies of three representative 'Kiowa' pecan trees measured below canopy at $\approx 1 \mathrm{~m}$ above the ground. Trees were either not pruned (NP), selectively pruned (SP), or pruned with mechanical hedger (HP). Light interception was measured near solar noon for the same three trees on three consecutive years (21 June 2003, 2 July 2004, and 19 July 2005) and it is expressed as percent of total solar radiation.

(Malstrom et al., 1982). In the same year, canopies of SP and NP trees intercepted $78 \%$ and $90 \%$ of the total solar radiation respectively. During the first part of the 2004 growing season, LAI levels were similar in all treatments. However, on the 17 Sept. measurement, LAI of HP trees was greater than NP and SP, which caused a significant increase in light interception in HP versus NP and SP (Fig. 3). The change in LAI and light interception during the second part of the 2004 growing season could be attributed to a second flush of vegetative growth - a phenomenon that occurs frequently in pecans in summer or fall in response to improved soil water availability or partial defoliation (Andersen and Brodbeck, 1988). The orchard used for the experiment was not irrigated but the elevated rainfall precipitation recorded in 2004 could explain the differences between the two years. In June 2004, recorded precipitation for the area was $298.5 \mathrm{~mm}$, which was more than six times the $48.8 \mathrm{~mm}$ of the 30 -year average for the same month and location. The reason why the second flush of vegetative growth was greater in HP than in SP and NP was not identified, but it is generally known that more severe pruning of a tree results in greater regrowth. In 2005, LAI and light interception in both SP and HP were similar to the NP values, thus indicating that the effects on canopy density observed after treatment application had been eliminated by vigorous growth. Analysis of the patterns of light interception during the experiment confirms that pruned canopies progressively closed to reach density levels similar to those obtained in NP trees (Fig. 2).

In 'Cape Fear' and 'Kiowa', total annual yield was unaffected by the treatments in the first two years after treatment application (Table 1). In 'Desirable', differences were observed only in 2004, when yield in the two pruning treatments doubled that of NP trees. In 2005, yield of HP 'Cape Fear' and 'Kiowa' trees was reduced compared with NP and SP trees. The reduction was particularly large in 'Cape Fear' in which the 2005 crop of HP trees was $31 \%$ and $33 \%$ of that of NP and SP trees respectively. In 'Kiowa', HP 2005 yield was $48 \%$ and $45 \%$ of that of NP and SP trees respectively. When total three-year yield was considered, 'Kiowa' yield was improved in SP $(24 \%)$ but decreased in HP. In 'Cape Fear', both pruning methods caused a reduction of yield when compared with unpruned trees. 'Desirable' was the only cultivar in which trees responded positively to pruning. Yield increase was actually proportional to the intensity of pruning, with SP and HP producing $15 \%$ and $32 \%$ respectively, more than NP (Table 1). These results are different from what found in a previous study (Worley, 1985), when 22-year-old 'Desirable' trees were pruned throughout an eight-year period. In that study, which was conducted near Albany, Ga., top and side hedging reduced the overall yield, whereas SP was not significantly different from the control. Dramatic climatic differences among pecan-growing regions, however, can alter the results of horticultural practices. This may explain why hedging of pecan trees, which is a standard procedure in the western United States, has yet to give promising results in the southeastern states (Georgia, Alabama).

Worley (1985) found that hedging changed the alternate bearing phase of 'Elliott' so that greater yields of pruned trees were obtained in "off" years of unpruned trees, and vice versa. In the current study, such effect was obtained only in HP 'Kiowa' in 2004 and 2005. If growers could prune to offset the alternate bearing cycle in certain parts of an orchard, they could reduce the severe yield fluctuations that characterize pecan production and price in the southeastern United States. Alternate bearing index ranges between 0 , when yields are identical every year, and 1 , when years with no crop are followed by years with production (Pearce and Doberšek-Urbanc, 1967). Pecan trees exhibit a strong tendency to vary production from year to year ("alternate bearing"). Such a phenomenon is present at the limb or shoot level, but it is usually more evident at the tree, orchard, regional, or even multiregional level (Wood, 1990). Despite years of research (Amling and Amling, 1983; Conner and Worley, 2000; Davis and Sparks, 1974; Reid et al., 1993; Smith et al., 1986, 1993; Sparks and Brack, 1972; Wood, 1989; Wood et al., 2003; Worley, 1979a, b, 1985; Worley and Mullinix, 1997; Worley et al., 1996), the physiology behind such phenomenon is only partially understood, and alternate bearing remains the principal challenge that the pecan industry faces year after year.

Although 'Cape Fear' is a cultivar that can produce regular crops as trees reach maturity (McEachern and Stein, 1997), the $I$ values calculated in this study indicated a tendency to alternate stronger than 'Desirable' and 'Kiowa' (Table 1). 'Desirable' is a standard commercial cultivar of the southeastern United States (McEachern and Stein, 1997) and has moderate but regular production of high-quality nuts, resulting in part to selfthinning June fruit drop (Grauke and Thompson, 1997). 'Kiowa', which was released by the U.S. Department of Agriculture in 1976, is fairly precocious but it tends to bear alternately as a mature tree (Madden et al., 1976). Conner and Worley (2000) reported an $I$ value of 0.73 for 'Kiowa' trees grown for more 20 years in southern Georgia. The authors also indicated that 'Kiowa' nut quality was lower in years with high crop load and that crop thinning was necessary to maintain good quality. In the current study, $I$ was unaffected by any of the treatments applied, which indicates that application of a single pruning did not help stabilize yield over time.

Pruning did not affect kernel percentage of 'Cape Fear' or 'Kiowa' in any of the years 

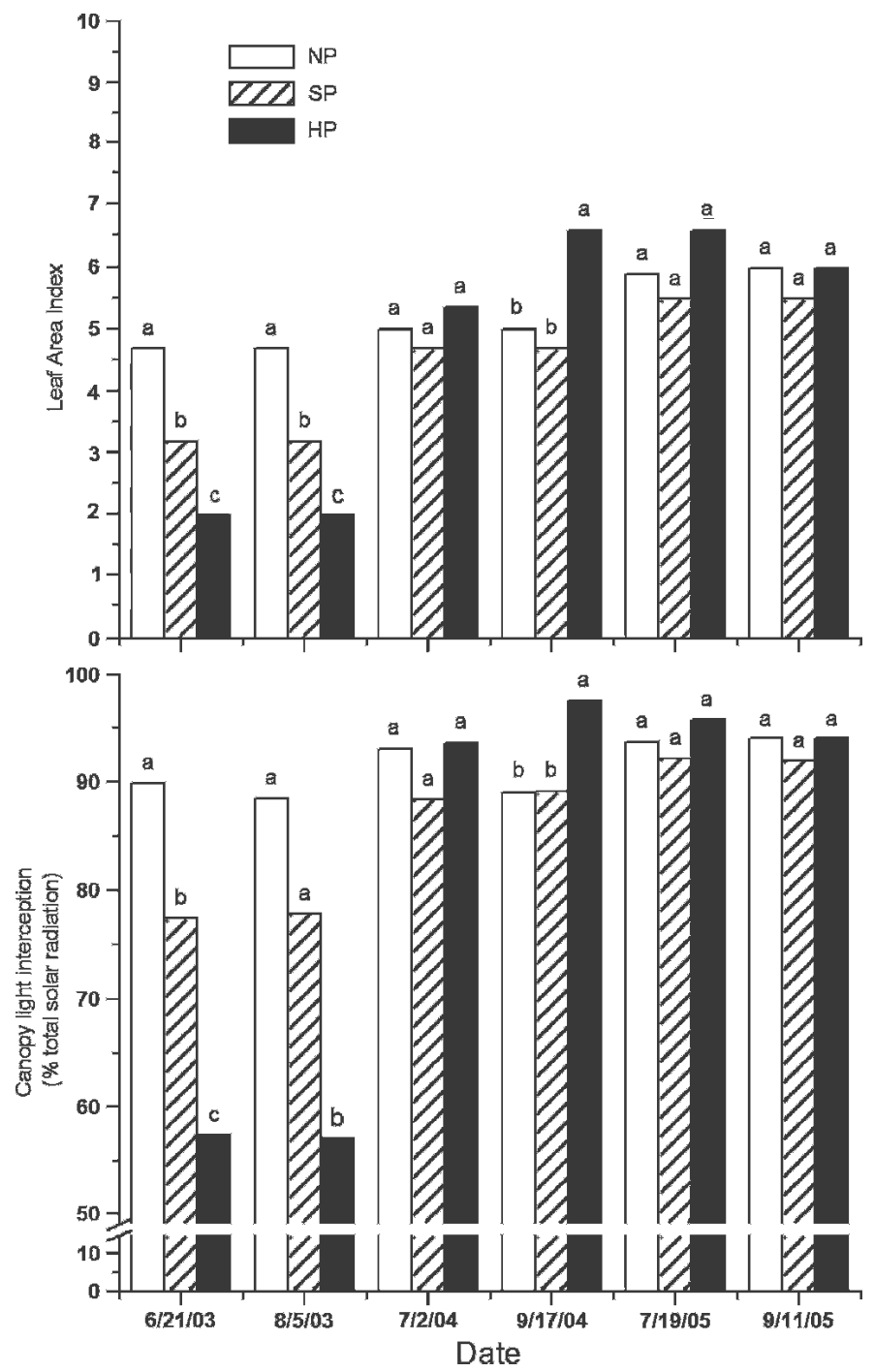

Fig. 3. Leaf area index (top) and canopy light interception (bottom) of 'Kiowa' pecan trees that were either not pruned (NP) or received two levels of canopy pruning (SP, selective pruning; HP, hedge pruning). Bars with different letters indicate significant differences within dates at $P \leq 0.05$.

investigated (Table 2). In 'Desirable', kernels harvested from HP had greater kernel percentage than NP trees (5\% and $9 \%$ greater in 2003 and 2004 respectively). However, no differences among treatments were observed in 'Desirable' in 2005. Pruning did not improve the overall quality of 'Kiowa' kernels (Table 2). Percent kernel was very low in 2005 across cultivars and treatments. This was likely incited by the drought conditions that characterized that growing season.

In 2003, the fraction of 'Cape Fear' and 'Desirable' kernels graded as either one of the top two quality categories ('Fancy' and 'Choice') was greater in HP than NP and SP. Such effect of improving kernel quality was not observed in the following years for 'Cape Fear', but the percent of better looking kernels observed in 2005 in 'Desirable' was again greater in HP than in NP $(77.9 \%$ and $46.6 \%$ respectively). The results found in this study are different from that previously reported (Worley, 1991). When mature ( $>50$ years old) 'Stuart' trees were subjected to selective limb pruning, the portion of
'Fancy' grade kernels was reduced compared with unpruned trees. Differences in the results may, however, derive from the fact that the two studies differed in the cultivar used, the age of the trees, and, again, geographical location.

\section{Conclusions}

Several pecan growers have been adopting pruning as a strategy to control canopy size, stabilize yield, and improve nut quality. Positive effects usually follow pruning; however, the high costs for time, labor, and equipment required limit pruning to large orchards. Hedge pruning is a common procedure for pecan trees grown in the irrigated desert areas, but results in more humid areas such as the southeastern United States have been inconsistent and short term. In the current study, the effects on light penetration, yield, and nut quality were investigated after a one-time canopy pruning of two different intensities. Although SP and HP induced some positive effects on light canopy trans- mission, yield, and nut quality, most of these effects were limited to 'Desirable' and disappeared by the third year after treatment application. 'Desirable' responded better than 'Cape Fear' to pruning, whereas no beneficial effects were recorded on 'Kiowa' yield and nut quality. Wood (1996) reported that 'Desirable' trees have a smaller scaffold angle and greater angle of lateral shoots at mid canopy than 'Cape Fear' and 'Kiowa'. It can be speculated that the different responses in yield and nut quality observed in the three cultivars were influenced by differences in canopy morphology and light interception.

The results of the current study indicate that one-time pruning did not induce a positive effect on light utilization, productivity, and nut quality of specific pecan cultivars. Further research should investigate whether repeated pruning may be necessary to induce beneficial effects.

\section{Literature Cited}

Amling, H.J. and K.A. Amling. 1983. Physiological differentiation of pistillate flowers of pecan and cold requirements for their initiation. J. Amer. Soc. Hort. Sci. 108:195-198.

Andersen, P.C. and B.V. Brodbeck. 1988. Net $\mathrm{CO}_{2}$ assimilation and plant water relations characteristics of pecan growth flushes. J. Amer. Soc. Hort. Sci. 113:444-450.

Breda, N.J.J. 2003. Ground-based measurements of leaf area index: A review of methods, instruments and current controversies. J. Expt. Bot. 54:2403-2417.

Brison, F.R. 1974. Pecan culture. Capital Printing, Austin, Tex.

Conner, P.J. and R.E. Worley. 2000. Alternate bearing intensity of pecan cultivars. HortScience 35:1067-1069.

Davis, J.T. and D. Sparks. 1974. Assimilation and translocation patterns of carbon-14 in shoot of fruiting pecan trees, Carya illinoensis Koch. J. Amer. Soc. Hort. Sci. 99:468-480.

Grauke, L.J. and T.E. Thompson. 1997. The Brooks and Olmo register of fruit and nut varieties. 3rd ed. ASHS Press, Alexandria, Va.

Latham, A.J. and W.D. Goff. 1990. Pecan scab: A review and control strategies, p. 89-93. In B.W. Wood, and J.A. Payne (eds.). Pecan husbandry: Challenges and opportunities. U.S Dept. Agr., Agr. Res. Serv. ARS-96.

Lombardini, L., M.K. Harris, and D.M. Glenn. 2005. Effects of particle film application on leaf gas exchange, water relations, nut yield, and insect populations in mature pecan trees. HortScience 40:1376-1380.

Madden, G.D., E.J. Brown, and H.L. Malstrom. 1976. Kiowa pecan. HortScience 11:522

Malstrom, H.L., T.D. Riley, and J.R. Jones. 1982 Continuous hedge pruning affects light penetration, and nut production of 'Western' pecan trees. Pecan Qrtly. 16:4-15.

McEachern, G.R. and L.A. Stein. 1997. Pecan varieties for Texas, p. III 1-5. In: G.R. McEachern, and L.A. Stein (eds.). Texas pecan handbook Texas Agr. Ext. Serv., College Station, Tex.

McEachern, G.R. and L.A. Stein. 2003. Thinning and hedging crowded pecan trees, p. 37-39. In L.A. Stein and G.R. McEachern (eds.). Texas pecan handbook. Vol. II. Texas Agr. Ext. Serv, College Station, Tex. 
Table 1. Yield of pecan trees that either were not pruned (NP) or received two types of winter canopy pruning (SP, selective pruning; HP, hedge pruning) during the dormant season 2003.

\begin{tabular}{|c|c|c|c|c|c|c|c|}
\hline \multirow[b]{2}{*}{ Cultivar } & \multirow[b]{2}{*}{ Treatment } & \multicolumn{4}{|c|}{ Annual yield $\left(\mathrm{kg} \cdot \mathrm{ha}^{-1}\right)$} & \multirow{2}{*}{$\begin{array}{c}\begin{array}{c}\text { Total yield } \\
\left(\mathrm{kg} \cdot \mathrm{ha}^{-1}\right)\end{array} \\
2003-05\end{array}$} & \multirow{2}{*}{$\begin{array}{l}\text { Alternate bearing } \\
\text { index }(I) \\
(2003-05)\end{array}$} \\
\hline & & 2003 & 2004 & 2005 & Avg. & & \\
\hline \multirow[t]{3}{*}{ Cape Fear } & NP & $666 a^{z}$ & $2090 \mathrm{a}$ & $538 \mathrm{a}$ & $1098 \mathrm{a}$ & 3083 & $0.57 \mathrm{a}$ \\
\hline & SP & $715 \mathrm{a}$ & 1934 a & $503 \mathrm{a}$ & $1051 \mathrm{a}$ & 2926 & $0.54 \mathrm{a}$ \\
\hline & HP & $978 \mathrm{a}$ & 1811 a & $165 \mathrm{~b}$ & $985 \mathrm{a}$ & 2730 & $0.53 \mathrm{a}$ \\
\hline \multirow[t]{3}{*}{ Desirable } & NP & $530 \mathrm{a}$ & $485 \mathrm{~b}$ & $1355 \mathrm{a}$ & $790 \mathrm{~b}$ & 2089 & $0.22 \mathrm{a}$ \\
\hline & SP & $522 \mathrm{a}$ & $952 \mathrm{a}$ & $1190 \mathrm{a}$ & $888 \mathrm{ab}$ & 2409 & $0.37 \mathrm{a}$ \\
\hline & HP & $578 \mathrm{a}$ & 993 a & $1442 \mathrm{a}$ & $1004 \mathrm{a}$ & 2748 & $0.27 \mathrm{a}$ \\
\hline \multirow[t]{3}{*}{ Kiowa } & NP & $371 \mathrm{a}$ & $746 \mathrm{a}$ & $1319 \mathrm{a}$ & $812 \mathrm{a}$ & 2175 & $0.41 \mathrm{a}$ \\
\hline & SP & $292 \mathrm{a}$ & $1237 \mathrm{a}$ & $1414 \mathrm{a}$ & $981 \mathrm{a}$ & 2693 & $0.31 \mathrm{a}$ \\
\hline & HP & $291 \mathrm{a}$ & $1101 \mathrm{a}$ & $634 \mathrm{~b}$ & $675 \mathrm{~b}$ & 1862 & $0.36 \mathrm{a}$ \\
\hline
\end{tabular}

${ }^{\mathrm{z}}$ Means within cultivar followed by different letters are significantly different at $P \leq 0.05$ by Fisher's LSD.

Table 2. Characteristics of pecan kernels harvested from trees that either were not pruned (NP) or received two types of canopy pruning (SP, selective pruning; HP, hedge pruning) during the dormant season 2003.

\begin{tabular}{|c|c|c|c|c|c|c|c|}
\hline \multirow[b]{2}{*}{ Cultivar } & \multirow[b]{2}{*}{ Treatment } & \multicolumn{3}{|c|}{ Kernel (\%) } & \multicolumn{3}{|c|}{ 'Fancy' + 'Choice' (\% total) } \\
\hline & & 2003 & 2004 & 2005 & 2003 & 2004 & 2005 \\
\hline \multirow[t]{3}{*}{ Cape Fear } & NP & $50.0 \mathrm{a}$ & $51.0 \mathrm{a}$ & $41.1 \mathrm{a}$ & $51.8 \mathrm{~b}$ & $39.0 \mathrm{a}$ & $63.8 \mathrm{a}$ \\
\hline & SP & $49.2 \mathrm{a}$ & $51.9 \mathrm{a}$ & $42.7 \mathrm{a}$ & $48.1 \mathrm{~b}$ & $39.0 \mathrm{a}$ & $69.9 \mathrm{a}$ \\
\hline & HP & $50.2 \mathrm{a}$ & $52.2 \mathrm{a}$ & $47.5 \mathrm{a}$ & $80.2 \mathrm{a}$ & $32.6 \mathrm{a}$ & $77.7 \mathrm{a}$ \\
\hline \multirow[t]{3}{*}{ Desirable } & NP & $50.0 \mathrm{~b}$ & $49.6 \mathrm{~b}$ & $46.0 \mathrm{a}$ & $40.0 \mathrm{~b}$ & $28.0 \mathrm{a}$ & $46.6 \mathrm{~b}$ \\
\hline & SP & $50.5 \mathrm{ab}$ & $51.2 \mathrm{ab}$ & $45.9 \mathrm{a}$ & $30.6 \mathrm{~b}$ & $27.0 \mathrm{a}$ & $56.7 \mathrm{ab}$ \\
\hline & HP & $52.5 \mathrm{a}$ & $54.0 \mathrm{a}$ & $45.0 \mathrm{a}$ & $70.6 \mathrm{a}$ & $47.1 \mathrm{a}$ & 77.9 a \\
\hline \multirow[t]{3}{*}{ Kiowa } & NP & $55.2 \mathrm{a}$ & $53.3 \mathrm{a}$ & $49.0 \mathrm{a}$ & $22.9 \mathrm{a}$ & $7.7 \mathrm{a}$ & $46.9 \mathrm{a}$ \\
\hline & SP & $56.0 \mathrm{a}$ & $55.3 \mathrm{a}$ & $51.4 \mathrm{a}$ & $27.4 \mathrm{a}$ & $6.7 \mathrm{a}$ & $64.4 \mathrm{a}$ \\
\hline & HP & $55.7 \mathrm{a}$ & $55.1 \mathrm{a}$ & $49.4 \mathrm{a}$ & $22.8 \mathrm{a}$ & $13.5 \mathrm{a}$ & $49.0 \mathrm{a}$ \\
\hline
\end{tabular}

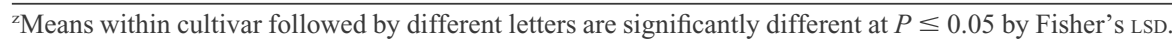

Pearce, S.C. and S. Doberšek-Urbanc. 1967. The measurement of irregularity in growth and cropping. J. Hort. Sci. 42:295-305.

Reid, W., S.M. Huslig, M.W. Smith, N.O. Maness, and J.M. Whitworth. 1993. Fruit-removal time influences return bloom in pecan. HortScience 28:800-802.

Smith, M.W., R.W. McNew, P.L. Ager, and B.C. Cotten. 1986. Seasonal changes in the carbohydrate concentration in pecan shoots and their relationship to flowering. J. Amer. Soc. Hort. Sci. 111:558-561.

Smith, M.W., W. Reid, B.L. Carroll, and B.S Cheary. 1993. Mechanical fruit thinning influ- between species and varieties, and within and between years. Ann. Bot. (Lond.) 11:41-76.

Wood, B.W. 1989. Pecan production responds to root carbohydrates and rootstock. J. Amer. Soc. Hort. Sci. 114:223-228.

Wood, B.W. 1990. Alternate bearing of pecan, p. 180-190. In: B.W. Wood and J.A. Payne (eds.). Pecan husbandry: Challenges and opportunities U.S. Dept. Agr., Agr. Res. Serv. ARS-96.

Wood, B.W. 1996. Canopy morphology of pecan cultivars. HortScience 31:139-142.

Wood, B.W., P.J. Conner, and R.E. Worley. 2003. Relationship of alternate bearing intensity in pecan to fruit and canopy characteristics. HortScience 38:361-366.

Wood, B.W. and D. Stahmann. 2004. Hedge pruning pecan. HortTechnology 14:63-72.

Woodroof, J.G. and N.C. Woodroof. 1934. Pecan root growth and development. J. Agr. Res. 49:511-530.

Worley, R.E. 1979a. Fall defoliation date and seasonal carbohydrate concentration of pecan wood tissue. J. Amer. Soc. Hort. Sci. 104:195199.

Worley, R.E. 1979b. Pecan yield, quality, nutlet set, and spring growth as a response to time of fall defoliation. J. Amer. Soc. Hort. Sci. 104:192-194.

Worley, R.E. 1985. Effects of hedging and selective limb pruning of Elliott, Desirable, and Farley pecan trees under three irrigation regimes. J. Amer. Soc. Hort. Sci. 110:12-16.

Worley, R.E. 1990. Pecan tree spacing and tree size, p. 142-151. In: B.W. Wood, and J.A. Payne (eds.). Pecan husbandry: Challenges and opportunities. U.S. Dept. Agr., Agr. Res. Serv. ARS-96.

ces fruit-quality, yield, return fruit-set, 1084.

Soil Survey Staff. 2004. Official soil series descriptions. Natural Resources Conservation Serv., U.S. Dept. Agr. 8 June 2006. http:// soils.usda.gov/technical/classification/osd/index. html.

Sparks, D. and C.E. Brack. 1972. Return bloom and fruit set of pecan from leaf and fruit removal. HortScience 7:131-132.

Watson, D.J. 1947. Comparative physiological studies on the growth of field crops. 1. Variation in net assimilation rate and leaf area
Worley, R.E. 1991. Selective limb pruning intensity influences mature pecan tree and nut characteristics. HortScience 26:126-129.

Worley, R.E. and B. Mullinix. 1997. Selective limb pruning of large pecan trees reduces yield but improves nut size and tree characteristics. HortScience 32:50-52.

Worley, R.E., B.G. Mullinix, and J.W. Daniel. 1996. Selective limb pruning, tree removal, and paclobutrazol growth retardant for crowding pecan trees. Sci. Hort. (Amsterdam) 67:79-85. 